\title{
IGF-1 induces cellular senescence in rat articular chondrocytes via Akt pathway activation
}

\author{
LI-DONG ZHAO, LIAN-YU BIE, LAN HU, ZI-HAN ZHU, XING-HUA MENG, \\ LIN-LIN CONG, SHAI ZHANG, NING MA and JIAN-HUA XIAO
}

\begin{abstract}
Heilongjiang Key Laboratory for Laboratory Animals and Comparative Medicine, College of Veterinary Medicine, Northeast Agricultural University, Harbin, Heilongjiang 150030, P.R. China
\end{abstract}

Received October 21, 2018; Accepted June 20, 2019

DOI: $10.3892 /$ etm.2020.9177

\begin{abstract}
Cellular senescence decreases cell proliferation over time and is characterized by typical markers, including larger cell volume, a flattened morphology, irreversible cell cycle arrest, augmentation of senescence-associated $\beta$-galactosidase (SA- $\beta$-gal) activity and senescence-associated secretory phenotype. A variety of factors are implicated in the process of cellular aging, which mediates an organisms' lifespan. Insulin-like growth factor-1 (IGF-1) serves an essential role in regulating cell growth, division, proliferation and senescence. In the present study, the role of IGF-1 and the downstream Akt signaling pathway in rat articular chondrocyte senescence was assessed. The results of the current study demonstrated that IGF-1 promoted cellular senescence in rat articular chondrocytes via activation of SA- $\beta$-gal and the upregulation of p53 and p21 mRNA and protein levels. IGF-1 enhanced Akt phosphorylation and treatment with Akt inhibitor, MK-2206, significantly suppressed the induction of these markers. Overall, the results indicated the involvement of IGF-1 and Akt in senescence exhibited by rat articular chondrocytes.
\end{abstract}

\section{Introduction}

Senescence is a complex process that has not yet been fully elucidated. Senescence is associated with the accumulation of toxic materials in cells. This accumulation leads to a decrease in cell physiological function and ultimately results in a variety of diseases (1). The number of cells exhibiting senescence increases with age and these cells exhibit an enlarged volume and flattened shape (2). Furthermore, specific markers including senescence-associated $\beta$-galactosidase (SA- $\beta$-gal) (3), the

Correspondence to: Professor Jian-Hua Xiao, Heilongjiang Key Laboratory for Laboratory Animals and Comparative Medicine, College of Veterinary Medicine, Northeast Agricultural University, 600 Changjiang Road, Harbin, Heilongjiang 150030, P.R. China

E-mail: xiaojianhua@neau.edu.cn

Key words: insulin-like growth factor-1, senescence, rat articular chondrocytes, Akt senescence-associated secretory phenotype (4) and an increased level of cell cycle inhibitors, including tumor protein p53, p21 and retinoblastoma-associated protein (5), have been identified as typical of senescent cells. The activation of these markers has been associated with a variety of different factors, including the presence of insulin-like growth factor 1 (IGF-1) (6,7).

IGF-1 was first discovered in 1957 (8) and has since been reported as being highly homologous with insulin (9). IGF-1 is also known as somatomedin $\mathrm{C}$ and is regulated by growth hormone and subsequently effects bodily functions (10) such as glucose metabolism and organ homeostasis (11). IGF-1 serves an important role in the regulation of cell growth, division and proliferation, and its aberrant expression can cause growth defects $(11,12)$. A number of studies have assessed the association between the insulin/IGF-1 signaling pathway and cell longevity and senescence (13-15). It has been previously reported that reduced IGF signaling leads to increased longevity $(16,17)$.

Cellular senescence contributes to aging and age-associated diseases including osteoarthritis (18). The presence of a variety of senescence markers has been observed in the chondrocytes of osteoarthritic lesions (19) and senescent chondrocytes (20). Furthermore, it has been reported that IGF-1 serves a key role in different cellular senescence types. Handayaningsih et al (21) demonstrated that IGF-1 enhanced the senescence of rat vascular smooth muscle cells, and mouse and human fibroblasts in vitro. However, the effect of IGF-1 on the premature senescence of rat articular chondrocytes is yet to be elucidated.

IGF-1 is a major regulator in a variety of tissue types and previous research has demonstrated that IGF-1 regulated numerous cell types through a variety of signaling pathways $(15,22)$. IGF-1 exerts a biological effect by activating the PI3K and ERK/mitogen-activated protein kinase (MAPK) pathways $(23,24)$. Furthermore, it has been revealed that IGF-1 stimulated proteoglycan synthesis via the PI3K pathway in chondrocytes (25). The activation of Akt has been indicated to be essential for IGF-1-induced survival signaling and has been previously suggested to be a target of IGF-1 signaling (26). Although the role of IGF-1 in the survival of some cell types has been clarified, the association between IGF-1 and Akt in rat articular chondrocyte senescence has not yet, to the best of 
our knowledge, been fully elucidated. The current study aimed to assess the effects of IGF-1 on rat articular chondrocyte senescence and focused on determining the molecular mechanisms underlying the activation of the Akt signaling pathway.

\section{Materials and methods}

Materials. Recombinant murine IGF-1 was obtained from PeproTech, Inc. The Akt inhibitor MK-2206 (MK) was purchased from Selleck Chemicals. A SA- $\beta$-gal staining kit was purchased from Beyotime Institute of Biotechnology. Anti-Akt rabbit pAb was purchased from Wanleibio Co., Ltd. (cat. no. WL0003b). p53 (cat. no. E1A6073), p21 (cat. no. E1 A6290) and phosphorylated p-Akt (Ser473) (cat. no. E1A0016) antibodies were obtained from EnoGene Biotech Co., Ltd. A rabbit monoclonal antibody against GAPDH was purchased from Abcam (cat. no. ab181602). Peroxidase-conjugated goat anti-rabbit IgG was purchased from Origene Technologies, Inc.

Isolation and culture of rat articular chondrocytes. All animal experiments were approved and conducted in accordance with the guidelines of the Ethical Committee for Animal Experiments (Northeast Agricultural University, Harbin, China). All rats had access to water and food ad libitum. Animals were purchased from the Animal Experimental Center of the Second Affiliated Hospital of the Harbin Medical University (Harbin, China) and housed in a controlled environment (light/dark, $12 / 12 \mathrm{~h}$; temperature $23 \pm 1^{\circ} \mathrm{C}$; relative humidity, $50-60 \%$. All rats were healthy upon purchase. The rats were observed for bite and skin damage daily; rats with skin damage were not used. All efforts were made to minimize suffering.

A total of 40 Sprague-Dawley rat pups (age, 17-21 days; weight, $30-40 \mathrm{~g}$ ) were used for chondrocyte preparation. Articular cartilage was aseptically isolated from the femoral condyle, tibial plateau and femoral heads of 17-21 day old Sprague-Dawley rat pups. Digestion was performed for $30 \mathrm{~min}$ at $37^{\circ} \mathrm{C}$ in a $50 \mathrm{ml}$ centrifuge tube containing $0.25 \%$ (w/v) trypsin (Gibco; Thermo Fisher Scientific, Inc.) by shaking at $85 \mathrm{rpm} / \mathrm{min}$. Trypsin was then removed and cartilage pieces were transferred into a new centrifuge tube and digested for $4 \mathrm{~h}$ at $37^{\circ} \mathrm{C}$ with $0.2 \%$ (w/v) collagenase II (Gibco; Thermo Fisher Scientific, Inc.) by shaking at $85 \mathrm{rpm} / \mathrm{min}$. The digested cartilage pieces were washed with equal quantities of DMEM/F-12 (Corning Inc.) supplemented with 10\% FBS (Biological Industries) and centrifuged at $400 \mathrm{x}$ g for $7 \mathrm{~min}$ at $4^{\circ} \mathrm{C}$. Obtained cells were then seeded in $25 \mathrm{~cm}^{2}$ sterile plastic culture flasks and incubated at $37^{\circ} \mathrm{C}$ in a $5 \% \mathrm{CO}_{2}$ incubator. The culture medium was changed every 2 days. Cells at the third and fifth passages were used for the subsequent experiments.

Treatment of rat articular chondrocytes. IGF-1 stock solution was prepared at $100 \mu \mathrm{g} / \mathrm{ml}$ in PBS according to manufacturer's protocol. MK was prepared as a $20 \mu \mathrm{M}$ stock solution in DMSO. DMSO was prepared as a $20 \mu \mathrm{M}$ stock solution in PBS. Cells sub-cultured from primary chondrocytes at $80 \%$ confluence were trypsinized and chondrocytes from the third and fifth passages were used in the subsequent experiments.
Chondrocytes at the third and fifth passages and at $80 \%$ confluence were serum-starved in DMEM containing 0.05\% FBS for $12 \mathrm{~h}$. Cells were divided at random into five groups, which were as follows: Control group (DMEM alone), IGF-1 group, MK + IGF-1 group, MK group, DMSO group. In the IGF-1 group, $10 \mu 1$ IGF-1 stock solution was added to DMEM at a final concentration of $100 \mathrm{ng} / \mathrm{ml}$. In the MK + IGF-1 group, cells were pretreated with MK $(5 \mu \mathrm{l})$ for $90 \mathrm{~min}$. Following IGF-1 $(100 \mathrm{ng} / \mathrm{ml})$ stimulation, cells were further cultured for $24 \mathrm{~h}$ at $37^{\circ} \mathrm{C}$. In the MK group, $5 \mu 1 \mathrm{MK}$ stock solution was added to DMEM at a final concentration of $10 \mathrm{nM}$. In the DMSO group, an equal volume of DMSO stock solution was added to DMEM to serve as a vehicle control. A previous study determined that there was no toxicity at the final concentration $0.02 \%$ of DMSO (27). Cells were incubated for $24 \mathrm{~h}$ at $37^{\circ} \mathrm{C}$ in a $95 \% \mathrm{O}_{2}$ humidified atmosphere with $5 \% \mathrm{CO}_{2}$ in DMEM containing $0.05 \%$ FBS.

Toluidine blue staining. Isolated chondrocytes were cultured in six-well plates at a density of $5.0 \times 10^{4}$ cell/well and subsequently stained at $80 \%$ confluence using the following procedure. Medium was removed and cells were washed with PBS. Cells were then fixed in $4 \%$ paraformaldehyde for $60 \mathrm{~min}$ at $4{ }^{\circ} \mathrm{C}$ and stained with a solution of $1 \%$ toluidine blue (Beijing Solarbio Science \& Technology Co., Ltd.) for $90 \mathrm{~min}$ at room temperature. Cells were rinsed for $3 \mathrm{~min}$, three times with PBS to remove the excess dye. The staining results were observed using an inverted light microscope (magnification, x100; Nikon Corporation).

Type II collagen immunofluorescence staining. Isolated chondrocytes were cultured in culture dishes at a density of $5.0 \times 10^{4} \mathrm{cell} /$ well and stained at $80 \%$ confluence using the following procedure. For type II collagen immunofluorescence staining, $4 \%$ paraformaldehyde was added and cells were fixed at $37^{\circ} \mathrm{C}$ for $30 \mathrm{~min}$. Permeabilization was performed using $0.1 \%$ Triton X-100/PBS for $20 \mathrm{~min}$. Cells were then blocked with $10 \%$ goat serum (Boster Biological Technology) for $30 \mathrm{~min}$ at room temperature and incubated overnight at $4^{\circ} \mathrm{C}$ with rabbit polyclonal antibody against collagen type II (cat. no. ab34712; Abcam, 1:200). Samples were washed with PBS and incubated at $37^{\circ} \mathrm{C}$ for $60 \mathrm{~min}$ with fluorescein-conjugated goat anti-rabbit IgG (cat. no. ZF-0311; OriGene Technologies, Inc.; 1:100). Samples were finally rinsed with PBS prior to nuclear staining with DAPI (Beyotime Institute of Biotechnology) for $5 \mathrm{~min}$ at room temperature. Images were analyzed using a fluorescence microscope (magnification, x200; Nikon Corporation). Clear fluorescence was observed under green light wavelength $543 \mathrm{~nm}$, blue light wavelength $458 \mathrm{~nm}$.

SA- $\beta$-gal activity assay for adherent cultured cells. After passages two and four chondrocytes were digested and cells were cultured at $37^{\circ} \mathrm{C}$ in six-well plates at a density of $5 \times 10^{4}$ cell/well for 20 days following the $24 \mathrm{~h}$ of aforementioned treatments at $37^{\circ} \mathrm{C}$ in a $95 \%$ humidified atmosphere with $5 \% \mathrm{CO}_{2}$ in DMEM containing $0.05 \%$ FBS. SA- $\beta$-gal activity assay was performed on all five experimental groups using a SA- $\beta$-gal staining kit according to manufacturer's protocol. Cells were fixed in fixative solution for $15 \mathrm{~min}$ at room temperature. Following washing with PBS, samples were incubated 
with freshly prepared SA- $\beta$-gal staining solution $(1 \mathrm{ml} /$ well containing $10 \mu \mathrm{l}$ of $\beta$-galactosidase staining solution $\mathrm{A}$ and $\mathrm{B}$, $930 \mu 1$ staining solution $\mathrm{C}$ and $50 \mu \mathrm{l} \mathrm{X}$-gal solution) overnight at $37^{\circ} \mathrm{C}$ in the dark without $\mathrm{CO}_{2}$. Cells were rinsed with PBS for $10 \mathrm{~min}$ and subsequently images were captured under an inverted light microscope. A total of 300 cells were counted in 3 random fields of view at x100 magnification to determine the percentage of positive blue staining cells, and quantitative analysis of SA- $\beta$-gal positive cells was performed for each group using Microsoft Excel 97-2003.

Reverse transcription-quantitative (RT-q)PCR analysis. After treatment for $24 \mathrm{~h}$, total RNA was extracted from $80 \%$ confluent rat articular chondrocytes using TRIzol ${ }^{\circledR}$ reagent (Invitrogen; Thermo Fisher Scientific, Inc.) according to the manufacturer's protocol. RNA concentration was evaluated at 260/280 nm using a spectrophotometer. Total RNA was reverse transcribed using PrimeScript ${ }^{\mathrm{TM}}$ RT Master Mix. According to the manufacturer's protocol (Takara Bio, Inc.), the protocol for reverse transcription was as follows: $37^{\circ} \mathrm{C}$ for $15 \mathrm{~min}, 85^{\circ} \mathrm{C}$ for $5 \mathrm{sec}$ and $4^{\circ} \mathrm{C}$ for $1 \mathrm{~min}$. The qPCR reaction system consisted of $2 \mu \mathrm{l}$ cDNA, $7 \mu \mathrm{l}$ RNase-free water, $0.5 \mu \mathrm{l}$ each of upstream and downstream primers at a concentration of $10 \mu \mathrm{M}$ with $10 \mu \mathrm{l}$ SYBR qPCR Master Mix (Toyobo Life Science). The relative expression of mRNA was quantified using RT-qPCR according to following protocols: $30 \mathrm{sec}$ of denaturation $\left(95^{\circ} \mathrm{C}\right)$, amplification consisted of $5 \mathrm{sec}$ of denaturation $\left(95^{\circ} \mathrm{C}\right)$ for 30 cycles, followed by $50 \mathrm{sec}$ of annealing $\left(34^{\circ} \mathrm{C}\right)$ and $72 \mathrm{sec}$ of extension $\left(72^{\circ} \mathrm{C}\right)$ steps in a LightCycler ${ }^{\circledR}$ 2.0 (Roche Diagnostics). GAPDH was used as a housekeeping gene. Primers were designed by Sangon Biotech Co., Ltd. and the primer sequences are as follows: p53 forward, 5'-TCC TCTGGGCCTTCTAACAAC-3' and reverse, 3'-CACAGT CGGATATGAGCATCG-5'; p21 forward, 5'-CTCCTGAGC CTGTTTCGTGTC-3' and reverse, 3'-CTCTGAAGATGT GCCTATGGT-5'; GAPDH forward, 5'-GATGCCCCCATG TTTGTGAT-3' and reverse, 3'-GGCATGGACTGTGGTCAT GAG-5'. The $2^{-\triangle \Delta C a}$ method was used to calculate differences in relative mRNA levels against GAPDH (28).

Western blot analysis. After treatment for $24 \mathrm{~h}$, western blot analysis was performed using standard procedures. Cells were lysed in RIPA buffer supplemented with $1 \mathrm{mM}$ PMSF. Protein concentration was measured by the bicinchoninic acid kit (Beyotime Institute of Biotechnology). A total of $30 \mu \mathrm{g}$ protein was loaded into an 5-13\% SDS-PAGE gel, separated and transferred to nitrocellulose filter membranes. Membranes were blocked with $5 \%$ nonfat dry milk for $2 \mathrm{~h}$ at room temperature and subsequently incubated in 5\% nonfat dry milk with corresponding primary antibodies (29), including GAPDH (1:5,000), Akt (1:500), p-Akt (Ser473; 1:500), p53 (1:500), p21 (1:500) overnight at $4^{\circ} \mathrm{C}$. Membranes were washed with TBST containing Tris-buffered saline and 0.1\% Tween-20. Following washing, membranes were incubated with peroxidase-conjugated goat anti-rabbit $\operatorname{IgG}(1: 1,000)$ for $1 \mathrm{~h}$ at $37^{\circ} \mathrm{C}$ and rinsed with TBST containing Tris-buffered saline and $0.1 \%$ Tween-20. The blots were developed using Luminata Crescendo Western HRP substrate (EMD Millipore) and were subsequently exposed to an Amersham Imager 600 (GE Healthcare Life Sciences). Subsequently, bands were quantified using Image $\mathbf{J} 1.50 \mathrm{i}$ software (National Institutes of Health).

Data analysis. All data were statistically analyzed using GraphPad Prism software (version 7.0; GraphPad Software, Inc.). Results are presented as the mean \pm standard deviation. Significant differences were analyzed by one-way ANOVA followed by Bonferroni's post hoc test. All data are representative of three independent experiments. $\mathrm{P}<0.05$ was considered to indicate a statistically significant difference.

\section{Results}

Identification of chondrocytes. Toluidine blue staining and type II collagen immunofluorescence staining were used for the identification of chondrocytes. In the present study, the strong toluidine blue staining of cytoplasm and membranes confirmed that cultured chondrocytes synthesized and secreted proteoglycan (Fig. 1A).

An evaluation of collagen type II expression in rat articular chondrocytes was performed in vitro. The results suggest that type II collagen was secreted by chondrocytes. Chondrocyte nuclei were stained blue with DAPI. The cultured chondrocytes maintained the characteristic of a phenotype expressing type II collagen (Fig. 1B).

Effects ofIGF-1 on SA- $\beta$-galactivity. Cellular senescence was confirmed using SA- $\beta$-gal staining, a biomarker of cellular senescence (3). The staining results revealed a blue-stained cytoplasm (Fig. 2A and C). The SA- $\beta$-gal-positive cells in the IGF-1 group which was significantly higher compared with the control group $(6.94 \pm 0.25 \%$ vs. $6.54 \pm 0.26 \%$; $\mathrm{P}<0.05$; Fig. 2B). When cells were pretreated with MK for $90 \mathrm{~min}$ prior to IGF-1 treatment, cells were SA- $\beta$-gal-positive and this was a significant reduction compared with the IGF-1 group $(6.17 \pm 0.29 \%$ vs. $6.94 \pm 0.25 \%$; $\mathrm{P}<0.05)$. No significant differences were observed in the DMSO group compared with the control group $(6.51 \pm 0.45 \%$ vs. $6.54 \pm 0.26 \%$; $\mathrm{P}>0.05)$. Similar trends were also observed in the fifth passage chondrocytes (Fig. 2D).

IGF-1 effects on the Akt signaling pathway. In order to elucidate the role of IGF-1 in the regulation of cellular senescence in rat articular chondrocytes, the effect of IGF-1 on cellular senescence in the third and fifth passages was assessed. The involvement of the Akt signaling pathway in the induction of cellular senescence by IGF-1 was also assessed. As presented in Fig. 3, in passages three and five, Akt was phosphorylated in chondrocytes with senescence induced upon IGF-1 stimulation compared with the control and DMSO groups. Treatment with MK, an Akt inhibitor, significantly decreased the IGF-1-induced activation of Akt and led to a decrease in phosphorylated Akt levels.

Effects of IGF-1 on p53 and p21 expression. The expression aging markers p53 and p21 were detected to further confirm the IGF-1-induced cellular senescence via the Akt signaling pathway (30). Relative levels of p53 and p21 mRNA were determined using RT-qPCR. Treatment with $100 \mathrm{ng} / \mathrm{ml}$ IGF-1 induced an increase in p53 mRNA in rat articular chondrocytes 
A

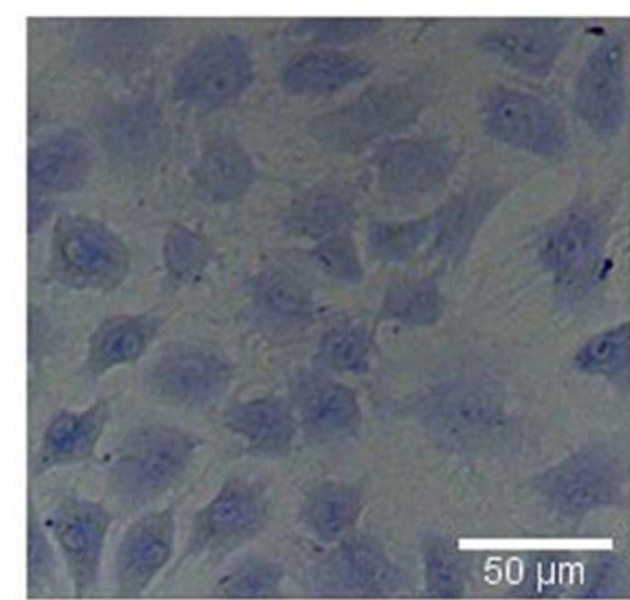

B

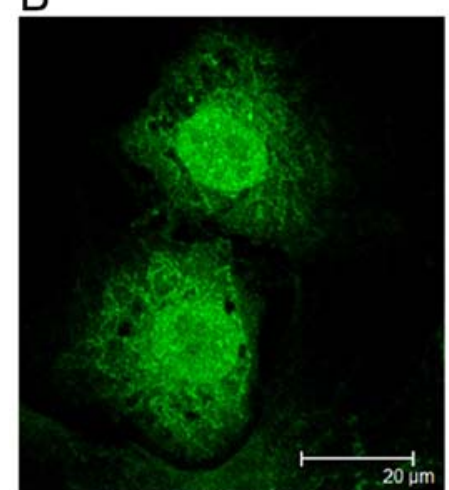

Type II collagen

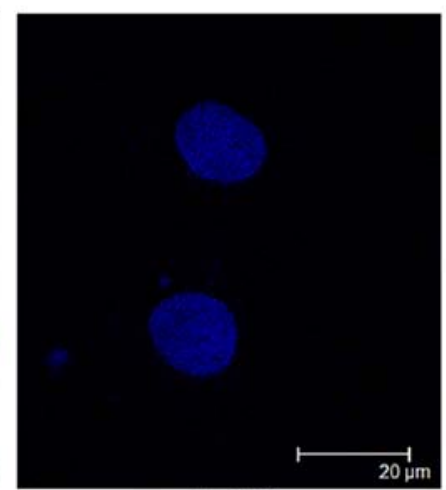

DAPI

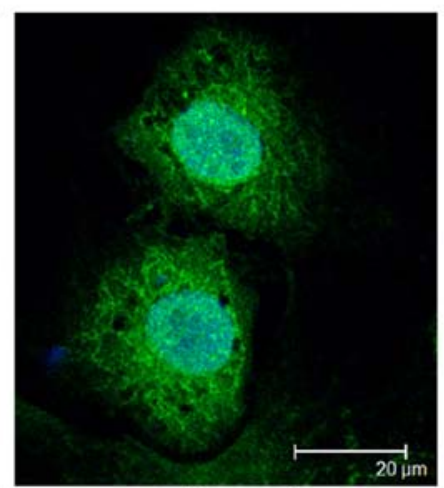

Merged

Figure 1. Identification of chondrocyte phenotypes. (A) Toluidine blue staining of chondrocytes. (B) Detection of type II collagen in in vitro-cultured rat articular chondrocytes using immunofluorescent staining.

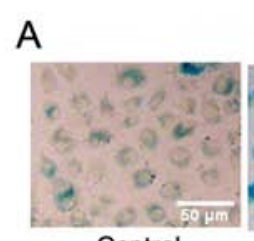

Control

C

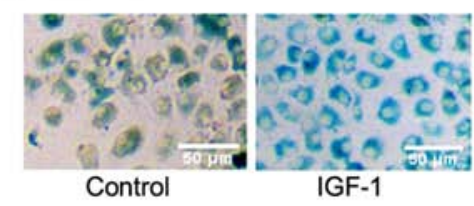

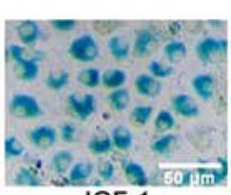

IGF-1

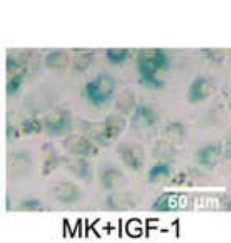

P3

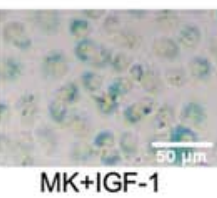

P5
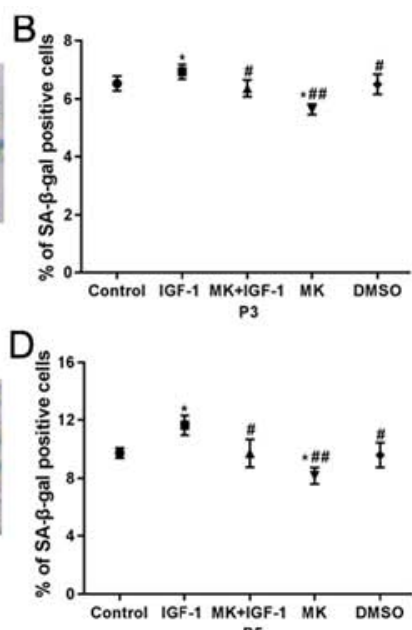

P5

Figure 2. Effects of IGF-1 on SA- $\beta$-gal activity. Senescent chondrocytes were stained for SA- $\beta$-gal activity and observed at x100 magnification. (A) Micrographs and (B) quantitative analysis of third passage chondrocytes and SA- $\beta$-gal-positive cell percentages in each group. Scale bar, $50 \mu \mathrm{m}$. (C) Micrographs and (D) quantitative analysis of fifth passage chondrocytes and SA- $\beta$-gal positive cell percentages in each group. Data are expressed as the mean \pm standard deviation of three random fields. " $\mathrm{P}<0.05$ vs. control; ${ }^{\#} \mathrm{P}<0.05$ and ${ }^{\# \#} \mathrm{P}<0.01$ vs. IGF-1. IGF-1, insulin-like growth factor-1; SA- $\beta$-gal, senescence-associated $\beta$-galactosidase; MK, MK-2206; P3, third passage; P5, fifth passage.

when compared with the control (15), and this effect was significantly decreased by pretreatment with MK (Fig. 4A). Subsequently, mRNA expression of p21 was assessed, a target gene of p53 (31). The mRNA expression of p21 was significantly higher in the IGF-1 group compared with the control group and was significantly decreased by pretreatment with MK (Fig. 4B). Chondrocytes at passages third and fifth exhibited similar trends. 

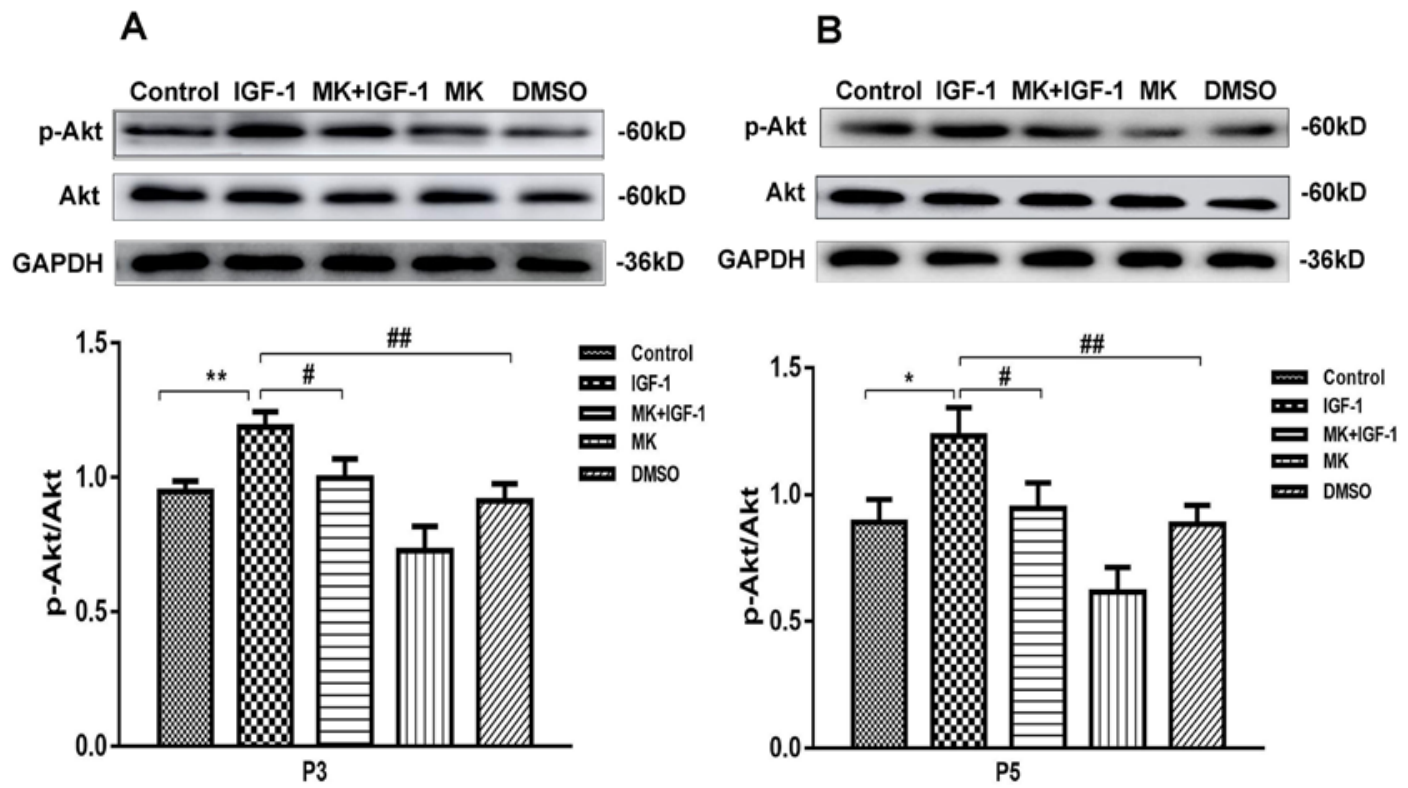

Figure 3. IGF-1 affects Akt activation at the third and fifth chondrocyte passages. Protein expression of p-Akt and Akt, was evaluated using western blot analysis in the third (A) and fifth (B) cell passages. Data are expressed as the mean \pm standard deviation of three random fields. Each value was normalized to GAPDH. ${ }^{*} \mathrm{P}<0.05$ and ${ }^{* *} \mathrm{P}<0.01$ vs. control; ${ }^{\#} \mathrm{P}<0.05$ and ${ }^{\# \#} \mathrm{P}<0.01$ vs. IGF-1. IGF-1, insulin-like growth factor-1; MK, MK-2206; $\mathrm{p}$, phosphorylated; $\mathrm{P}$ 3, third passage; P5, fifth passage.
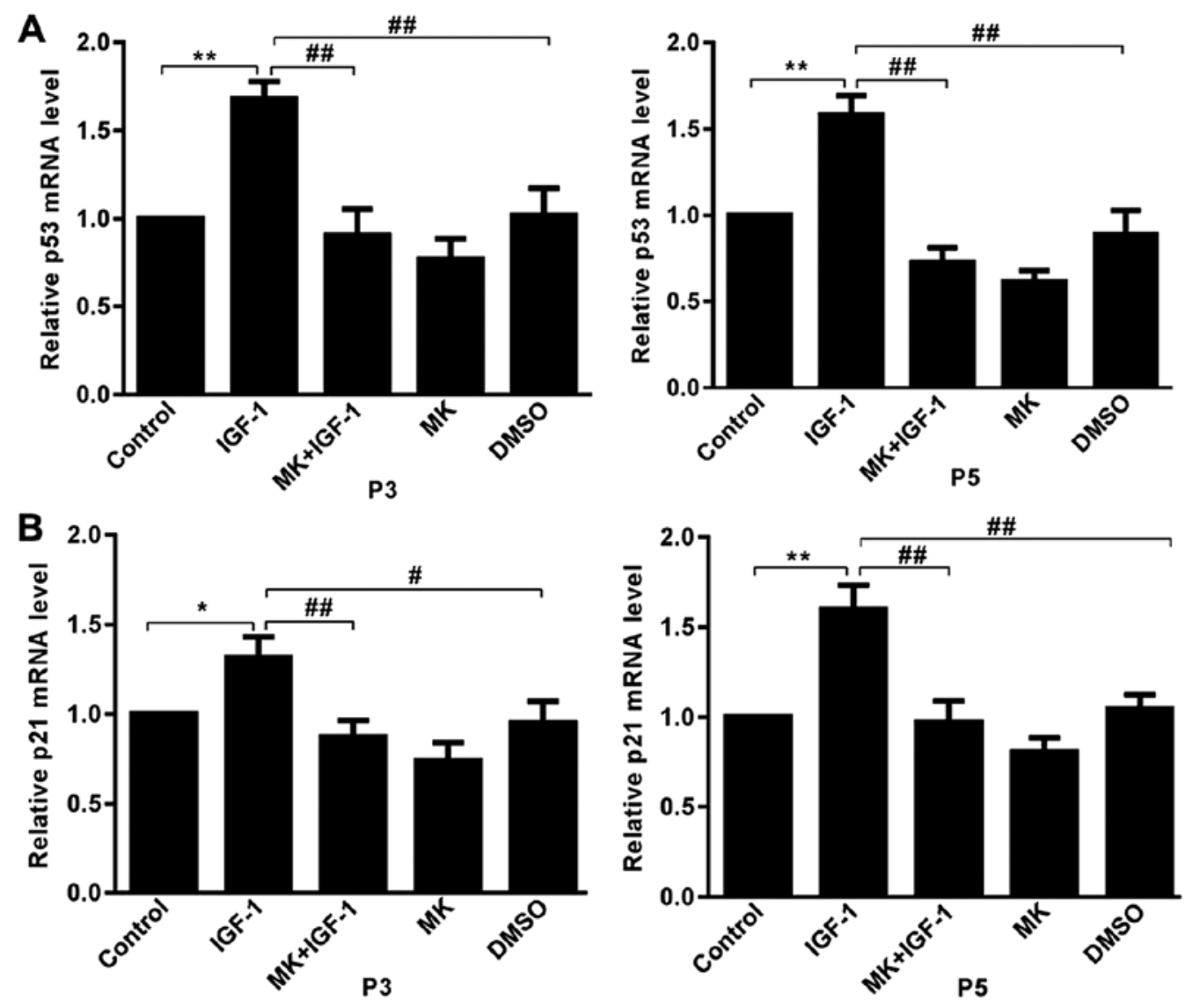

Figure 4. Analysis of the IGF-1-induced cellular senescence-associated gene expression. Relative mRNA expression of (A) p53 and (B) p21 was assessed using reverse-transcription-quantitative $\mathrm{PCR}$ for the third and fifth passages. Data are expressed as the mean \pm standard deviation of three random fields. ${ }^{*} \mathrm{P}<0.05$ and ${ }^{* *} \mathrm{P}<0.01$ vs. control; ${ }^{\#} \mathrm{P}<0.05$ and ${ }^{\# \#} \mathrm{P}<0.01$ vs. IGF-1. IGF-1, insulin-like growth factor-1; MK, MK-2206; P3, third passage; P5, fifth passage.

p53 and p21 protein expression was subsequently detected using western blot analysis (Fig. 5A and B). In passages three and five, when compared with the control group, p53 and p21 protein expression was significantly increased in the presence of IGF-1 $(\mathrm{P}<0.01)$. Following incubation with MK+IGF-1, p53 and p21 protein expression 

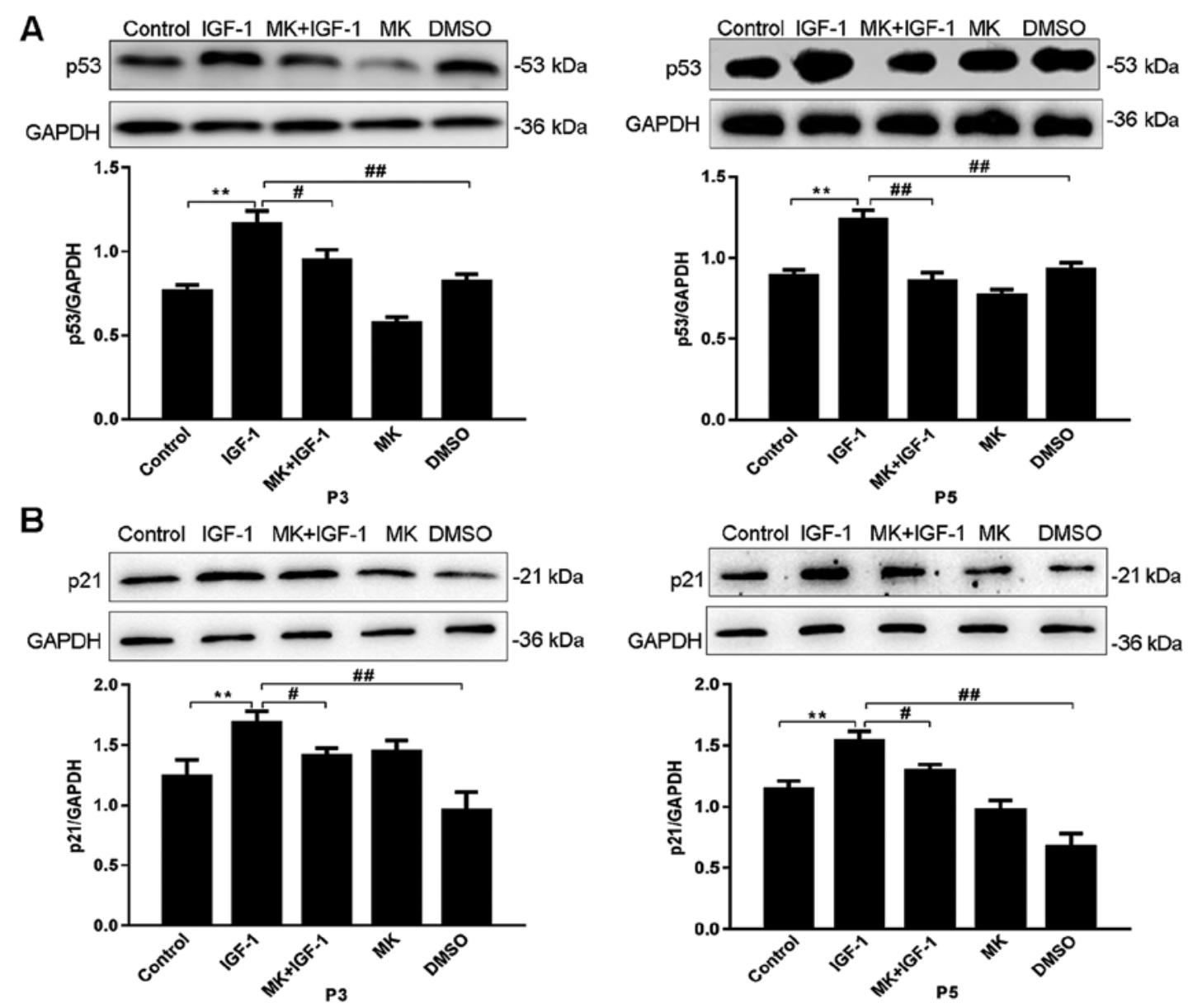

Figure 5. Analysis of IGF-1-induced cellular senescence-associated protein expression. Protein expression of (A) p53 and (B) p21, was evaluated using western blot analysis in the third and fifth cell passages. Data are expressed as the mean \pm standard deviation of three random fields. ${ }^{* * *} \mathrm{P}<0.01 \mathrm{vs}$. control; " $\mathrm{P}<0.05$ and ${ }^{\# \prime} \mathrm{P}<0.01$ vs. IGF-1. IGF-1, insulin-like growth factor-1; MK, MK-2206; P3, third passage; P5, fifth passage.

levels were significantly reduced compared with the IGF-1 group $(\mathrm{P}<0.05)$.

\section{Discussion}

Several studies assessing cellular senescence have previously demonstrated that IGF-1 induced cellular senescence in multiple cell types $(21,22)$. The results of the present study demonstrated a similar process occurring in rat articular chondrocytes. The results revealed that IGF-1 promoted cellular senescence, increased SA- $\beta$-gal staining and increased senescence-associated p53 and p21 expression. SA- $\beta$-gal activity is a typical biomarker of cellular senescence. SA- $\beta$-gal has been revealed to be expressed in senescent cells, but not in pre-senescent or quiescent fibroblasts and not in early passage terminally differentiated keratinocytes (3). A variety of other cell types have also been reported to express SA- $\beta$-gal. For example, in a previous study, human prostatic epithelial cells exhibited extensive expression of SA- $\beta$-gal during prolonged culture (32). The activity of SA- $\beta$-gal has also been revealed to increase in senescent human endothelial cells (33).

A previous study demonstrated that chondrocyte senescence serves an essential role in the cartilage degeneration that occurs with aging and also increases with subculture-induced dedifferentiation of chondrocytes (34). A previous study reported that chondrocyte viability was high in early passages and reduced in later passages. Chondrocytes appeared fibroblast-like after the seventh passage (35). As the passage number increased, cell growth rate and viability decreased. The percentage of SA- $\beta$-gal positive cells was 26 and 52\% in third and fifth passage chondrocytes, respectively (35). Although the proliferative activity of chondrocytes within early passages is high, cells in late passages no longer exhibit high proliferative activity (36). Therefore, third and fifth passage cells were used in the present study. To synchronize cells and avoid serum interference with drugs, cells were serum-starved for $12 \mathrm{~h}$ in DMEM containing 0.05\% FBS. IGF-1 was used to induce cells in serum-free or low-concentration serum DMEM, a method which has been previously revealed to exhibit no effect on cell growth $(15,21,22,37)$. In the current study, the results of SA- $\beta$-gal staining revealed an upregulation of positive cells upon IGF-1 treatment in the third and fifth passage chondrocytes. The number of positive cells in the fifth generation chondrocytes was higher compared with the third generation. These results indicated that senescent cells increased over time. The results are in agreement with those reported by Handayaningsih et al (21) who demonstrated that IGF-1 significantly enhanced cell senescence.

In the present study, other aging markers were additionally assessed, including p53 and p21 expression. Tumor suppressor 
protein p53 is one of the major biochemical mediators of senescence in human cells which induces p21 expression $(30,31)$. P53 and p21 are directly associated with cellular senescence and have been used to identify senescent cells (38). p53 is associated with lifespan regulation and is a critical meditor of the senescence response to a variety of stimuli $(39,40)$. It has been previously reported that p53 is activated and accumulates in senescent fibroblasts (39). A recent study has demonstrated that senescence-associated p53 level increased in aged mouse cardiomyocytes (40). p21 is a downstream target of p53 and is directly regulated by p53 $(38,41)$. p21 expression has been revealed to increase in human fibroblasts upon replicative senescence $(42,43)$. In the present study, p53 and p21 mRNA expression was significantly higher in the IGF-1 group compared with control cells. Furthermore, it has been described that IGF-1 treatment performed on IMR90 or MEF cells led to the appearance of cells with premature cellular senescence characteristics, including the upregulation of p53 and p21 proteins (22). These data are consistent with the results obtained in the present study demonstrating that p53 and p21 protein expression was enhanced upon IGF-1 treatment. It may be concluded that IGF-1 induced cellular senescence in rat articular chondrocytes.

The associated signaling pathways were assessed to determine the mechanisms underlying cellular senescence induced by IGF-1. Two main pathways have been previously revealed to be associated with IGF-1 activity, including the PI3K/Akt and MAPK/ERK pathways $(23,24)$. Various studies have suggested that senescence was mediated by activating the Akt signaling pathway (44), and IGF-1 stimulation lead to the activation of the PI3K/Akt pathway (45). Therefore, the current study assessed the ability of IGF-1 to activate Akt and aimed to determine whether the Akt pathway was associated with rat articular chondrocyte senescence. The Akt phosphorylation in the IGF-1 group which was significantly higher compared with the control group, which demonstrated that Akt was activated by IGF-1. Additionally, the chemical inhibition of Akt by MK led to the significant inhibition of Akt phosphorylation induced by IGF-1 activation. Overall, the results of the present study indicated that the inhibition of the Akt signaling pathway reversed IGF-1 induction. Further experiments should aim to clarify the involvement of other signaling pathways in rat articular chondrocyte senescence.

In conclusion, the results of the present study demonstrated that IGF-1 induced senescence in rat articular chondrocytes and activated the PI3K/Akt pathway.

\section{Acknowledgements}

Not applicable.

\section{Funding}

The present study was supported by The National Key R\&D Program of China (grant no. 2017YFD0502202).

\section{Availability of data and materials}

The datasets used and/or analyzed during the current study are available from the corresponding author on reasonable request.

\section{Authors' contributions}

LZ, LB and JX conceived and designed the study. LH, ZZ, LC $\mathrm{XM}$ and $\mathrm{NM}$ were responsible for the collection and analysis of the data. LZ, SZ and JX interpreted the data and drafted the manuscript. LZ and JX revised the manuscript critically for important intellectual content. All authors read and approved the final manuscript.

\section{Ethics approval and consent to participate}

The current study was approved by The Ethical Committee for Animal Experiments (Northeast Agricultural University, Harbin, China).

\section{Patient consent for publication}

Not applicable.

\section{Competing interests}

The authors declare that they have no competing interests.

\section{References}

1. Childs BG, Durik M, Baker DJ and van Deursen JM: Cellular senescence in aging and age-related disease: From mechanisms to therapy. Nat Med 21: 1424-1435, 2015.

2. Muñoz-Espín D and Serrano M: Cellular senescence: From physiology to pathology. Nat Rev Mol Cell Biol 15: 482-496, 2014.

3. Dimri GP, Lee X, Basile G, Acosta M, Scott G, Roskelley C, Medrano EE, Linskens M, Rubelj I and Pereira-Smith O: A biomarker that identifies senescent human cells in culture and in aging skin in vivo. Proc Natl Acad Sci USA 92: 9363-9367, 1995.

4. Tchkonia T, Zhu Y, van Deursen J, Campisi J and Kirkland JL: Cellular senescence and the senescent secretory phenotype: Therapeutic opportunities. J Clin Invest 123: 966-972, 2013.

5. Hall BM, Balan V, Gleiberman AS, Strom E, Krasnov P, Virtuoso LP, Rydkina E, Vujcic S, Balan K, Gitlin I, et al: Aging of mice is associated with p16(Ink4a)- and $\beta$-galactosidase-positive macrophage accumulation that can be induced in young mice by senescent cells. Aging (Albany NY) 8: 1294-1315, 2016.

6. Kenyon C: The first long-lived mutants: Discovery of the insulin/IGF-1 pathway for ageing. Philos Trans R Soc Lond B Biol Sci 366: 9-16, 2011.

7. Lee C, Wan J, Miyazaki B, Fang Y, Guevara-Aguirre J, Yen K, Longo V, Bartke A and Cohen P: IGF-I regulates the age-dependent signaling peptide humanin. Aging Cell 13: 958-961, 2014.

8. Salmon WD Jr and Daughaday WH: A hormonally controlled serum factor which stimulates sulfate incorporation by cartilage in vitro. 1956. J Lab Clin Med 116: 408-419, 1990.

9. Rinderknecht $\mathrm{E}$ and Humbel RE: The amino acid sequence of human insulin-like growth factor I and its structural homology with proinsulin. J Biol Chem 253: 2769-2776, 1978.

10. Daughaday WH, Hall K, Raben MS, Salmon WD Jr, van den Brande JL and van Wyk JJ: Somatomedin: Proposed designation for sulphation factor. Nature 235: 107, 1972.

11. Powell-Braxton L, Hollingshead P, Warburton C, Dowd M, Pitts-Meek S, Dalton D, Gillett N and Stewart TA: IGF-I is required for normal embryonic growth in mice. Genes Dev 7: 2609-2617, 1993.

12. Costales $\mathbf{J}$ and Kolevzon A: The therapeutic potential of insulin-like growth factor-1 in central nervous system disorders. Neurosci Biobehav Rev 63: 207-122, 2016.

13. Castilla-Cortazar I, Guerra L, Puche JE, Muñoz U, Barhoum R, Escudero E and Lavandera JL: An experimental model of partial insulin-like growth factor-1 deficiency in mice. J Physiol Biochem 70: 129-139, 2014. 
14. De Ita JR, Castilla-Cortázar I, Aguirre GA, Sánchez-Yago C, Santos-Ruiz MO, Guerra-Menéndez L, Martín-Estal I, García-Magariño M, Lara-Díaz VJ, Puche JE and Muñoz U: Altered liver expression of genes involved in lipid and glucose metabolism in mice with partial IGF-1 deficiency: An experimental approach to metabolic syndrome. J Transl Med 13: 326, 2015.

15. Nishizawa H, Iguchi G, Fukuoka H, Takahashi M, Suda K, Bando H, Matsumoto R, Yoshida K, Odake Y, Ogawa W and Takahashi Y: IGF-I induces senescence of hepatic stellate cells and limits fibrosis in a p53-dependent manner. Sci Rep 6: 34605, 2016

16. $\mathrm{Xu}$ J, Gontier G, Chaker Z and Lacube P, Dupont J and Holzenberger M: Longevity effect of IGF-1R(+/-) mutation depends on genetic background-specific receptor activation. Aging Cell 13: 19-28, 2014

17. Di Bona D, Accardi G, Virruso C, Candore G and Caruso C: Association of Klotho polymorphisms with healthy aging: A systematic review and meta-analysis. Rejuvenation Res 17: 212-216, 2014.

18. Lotz M and Loeser RF: Effects of aging on articular cartilage homeostasis. Bone 51: 241-248, 2012.

19. Price JS, Waters JG, Darrah C, Pennington C, Edwards DR, Donell ST and Clark IM: The role of chondrocyte senescence in osteoarthritis. Aging Cell 1: 57-65, 2002.

20. McCulloch K, Litherland GJ and Rai TS: Cellular senescence in osteoarthritis pathology. Aging Cell 16: 210-218, 2017.

21. Handayaningsih AE, Takahashi M, Fukuoka H, Iguchi G, Nishizawa H, Yamamoto M, Suda K and Takahashi Y: IGF-I enhances cellular senescence via the reactive oxygen species-p53 pathway. Biochem Biophys Res Commun 425: 478-484, 2012.

22. Tran D, Bergholz J, Zhang HB, He HB, Wang Y, Zhang YJ Li QT, Kirkland JL and Xiao ZX: Insulin-like growth factor-1 regulates the SIRT1-p53 pathway in cellular senescence. Aging Cell 13: 669-678, 2014.

23. Zhang M, Zhou Q, Liang QQ, Li CG, Holz JD, Tang D, Sheu TJ, Li TF, Shi Q and Wang YJ: IGF-1 regulation of type II collagen and MMP-13 expression in rat endplate chondrocytes via distinct signaling pathways. Osteoarthritis Cartilage 17: 100-106, 2009.

24. Ock S, Lee WS, Ahn J, Kim HM, Kang H, Kim HS, Jo D, Abel ED, Lee TJ and Kim J: Deletion of IGF-1 receptors in cardiomyocytes attenuates cardiac aging in male mice. Endocrinology 157 336-345, 2016

25. Starkman BG, Cravero JD, Delcarlo M and Loeser RF: IGF-I stimulation of proteoglycan synthesis by chondrocytes requires activation of the PI 3-kinase pathway but not ERK MAPK. Biochem J 389: 723-729, 2005.

26. Kulik G and Weber MJ: Akt-dependent and -independent survival signaling pathways utilized by insulin-like growth factor I. Mol Cell Biol 18: 6711-6718, 1998.

27. Panganiban RAM and Day RM: Inhibition of IGF-1R prevents ionizing radiation-induced primary endothelial cell senescence. PLoS One 8: e78589, 2013.

28. Livak KJ and Schmittgen TD: Analysis of relative gene expression data using real-time quantitative PCR and the 2(-Delta Delta C(T)) method. Methods 25: 402-408, 2001

29. Xu XX, Zhang XH, Diao Y and Huang YX: Achyranthes bidentate saponins protect rat articular chondrocytes against interleukin-1 $\beta$ induced inflammation and apoptosis in vitro. Kaohsiung J Med Sci 33: 62-68, 2017.

30. Jiang CS, Liu G, Luckhardt T, Antony V, Zhou Y, Carter AB, Thannickal VJ and Liu RM: Serpine 1 induces alveolar type II cell senescence through activating $\mathrm{p} 53-\mathrm{p} 21-\mathrm{Rb}$ pathway in fibrotic lung disease. Aging Cell 16: 1114-1124, 2017.
31. el-Deiry WS, Tokino T, Velculescu VE, Levy DB, Parsons R, Trent JM, Lin D, Mercer WE, Kinzler KW and Vogelstein B: WAF1, a potential mediator of p53 tumor suppression. Cell 75: 817-825, 1993

32. Choi J, Shendrik I, Peacocke M, Peehl D, Buttyan R, Ikeguchi EF, Katz AE and Benson MC: Expression of senescence-associated beta-galactosidase in enlarged prostates from men with benign prostatic hyperplasia. Urology 56: 160-166, 2000.

33. Kurz DJ, Decary S, Hong Y and Erusalimsky JD Senescence-associated (beta)-galactosidase reflects an increase in lysosomal mass during replicative ageing of human endothelial cells. J Cell Sci 113: 3613-3622, 2000.

34. Loeser RF: Aging and osteoarthritis: The role of chondrocyte senescence and aging changes in the cartilage matrix. Osteoarthritis Cartilage 17: 971-979, 2009.

35. Liu ZM, Shen PC, Lu CC, Chou SH and Tien YC: Characterization of the proliferating layer chondrocytes of growth plate for cartilage regeneration. Tissue Eng Part A 25: 364-378, 2019

36. Kang SW, Yoo SP and Kim BS: Effect of chondrocyte passage number on histological aspects of tissue-engineered cartilage. Biomed Mater Eng 5: 269-276, 2007.

37. Handayaningsih AE, Iguchi G, Fukuoka H, Nishizawa H, Takahashi M, Yamamoto M, Herningtyas EH, Okimura Y, Kaji $\mathrm{H}$, Chihara $\mathrm{K}$, et al: Reactive oxygen species play an essential role in IGF-I signaling and IGF-I-induced myocyte hypertrophy in C2C12 myocytes. Endocrinology 152: 912-921, 2011.

38. Itahana K, Dimri G and Campisi J: Regulation of cellular senescence by p53. Eur J Biochem 268: 2784-2791, 2001.

39. Atadja P, Wong H, Garkavtsev I, Veillette C and Riabowol K: Increased activity of p53 in senescing fibroblasts. Proc Natl Acad Sci USA 92: 8348-8352, 1995.

40. Wang Z, Rong X, Luo B, Qin S, Lu L, Zhang X, Sun Y, Hu Q and Zhang C: A natural model of mouse cardiac myocyte senescence. J Cardiovase Transl Res 9: 456-458, 2016.

41. Jackson JG and Pereira-Smith OM: p53 is preferentially recruited to the promoters of growth arrest genes p21 and GADD45 during replicative senescence of normal human fibroblasts. Cancer Res 66: 8356-8360, 2006.

42. Herbig U, Jobling WA, Chen BP, Chen DJ and Sedivy JM Telomere shortening triggers senescence of human cells through a pathway involving ATM, p53, and p21(CIP1), but not p16(INK4a). Mol Cell 14: 501-513, 2004.

43. Dimri GP, Testori A, Acosta M and Campisi J: Replicative senescence, aging and growth-regulatory transcription factors. Biol Signals 5: 154-162, 1996

44. Chen ZB, Trotman LC, Shaffer D, Lin HK, Dotan Z, Niki M, Koutcher JA, Scher HI, Ludwig T, Gerald W, et al: Crucial role of p53-dependent cellular senescence in suppression of Pten-deficient tumorigenesis. Nature 436: 725-730, 2005.

45. Blume-Jensen $\mathrm{P}$ and Hunter T: Oncogenic kinase signalling. Nature 411: 355-365, 2001.

This work is licensed under a Creative Commons Attribution-NonCommercial-NoDerivatives 4.0 International (CC BY-NC-ND 4.0) License. 